\title{
PHYSICAL PROPERTIES OF THE SKIN IN THE EHLERS-DANLOS SYNDROME*
}

\author{
BY \\ R. GRAHAME $\dagger$ AND P. BEIGHTON $\ddagger$ \\ From the Clinical Research Division, Kennedy Institute of Rheumatology, London, W.6, and \\ St. Thomas's Hospital, London
}

Although hyperextensibility of the skin is a prominent feature of the Ehlers-Danlos syndrome (EDS), there have been few objective measurements of the physical properties of the skin in this condition. The purpose of this paper is to describe the results of certain measurements and to discuss their significance in the light of present theories of the nature of the basic defect in the EDS.

\section{Description of the Syndrome}

The skin may be stretched for several centimetres, and on release it springs back to resume its former contour (Fig. 1). In the past this feature has permitted affected individuals to earn their living as

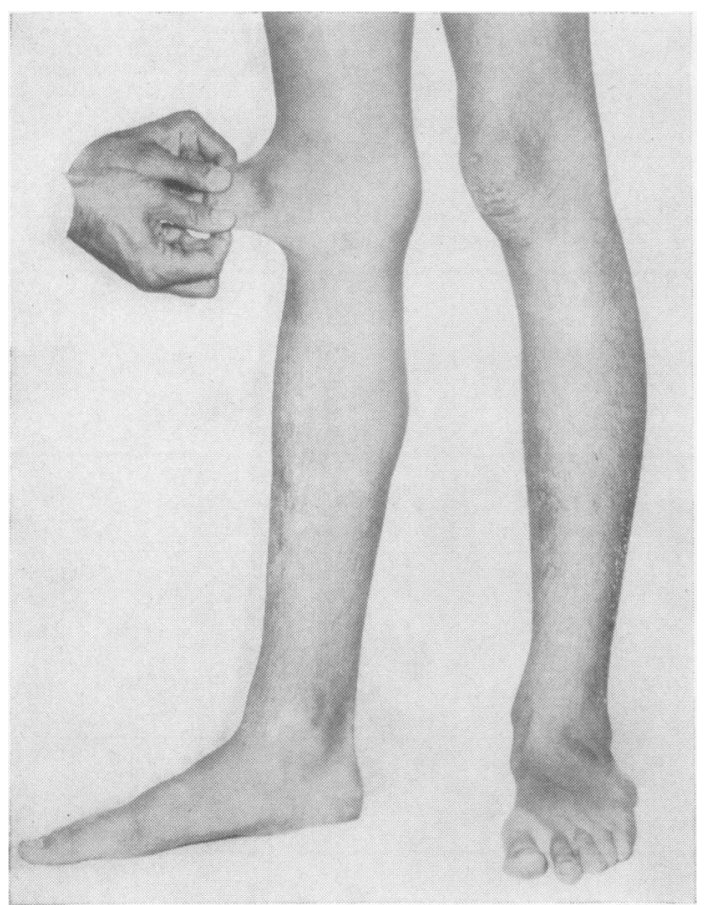

Fig. 1. Skin hyperextensibility, pes planus, and typical scars over the knees and shins.

*Read to the Heberden Society on February 14, 1969.

$\dagger$ Present address: Department of Physical Medicine, Guy's Hospital, London, S.E.1.

IPresent address: Johns Hopkins Hospital, Baltimore. circus exhibitionists. One gentleman made his name by his ability to place six golf balls in his mouth at the same time (Duperrat, 1965). Another well-known clown could touch his nose with his bottom lip. A photograph of an "Elastic Lady", which was found in a Hampstead fairground peepshow, is shown in Fig. 2. Pride of place must go to the Spaniard, George Albes, who in 1657 demonstrated before the physicians of the Academy of Leiden "the extraordinary dilatability of his skin, which could be stretched to half an eil"* (van Meekeren, 1682). In a contemporary portrait he is depicted pulling up the skin of his chest to touch his chin.

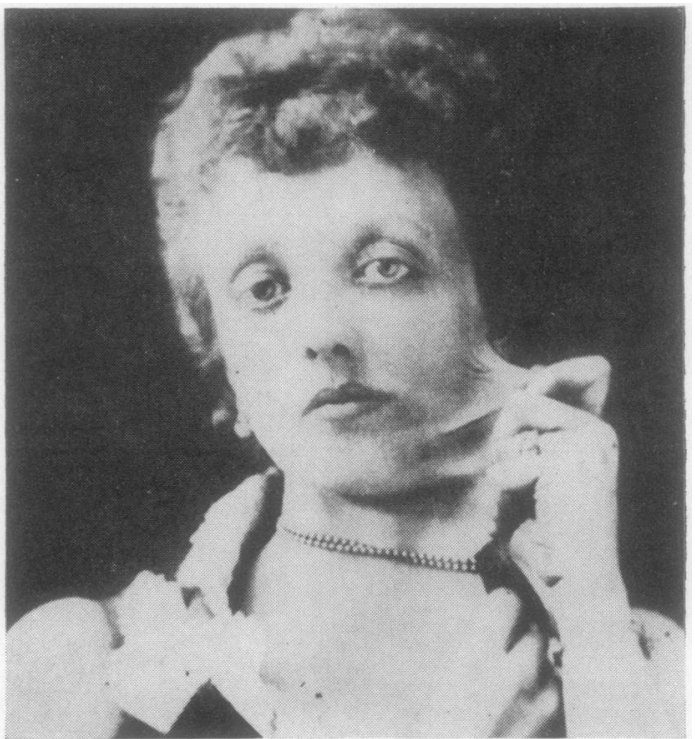

Fig. 2.-“Etta Lake, The Elastic Lady". A circus exhibitionist of 1910.

Fragility of the skin is also present, and the face and bony prominences are frequently covered with thin gaping scars (Fig. 3). The joints are hypermobile (Fig. 4), and ocular, visceral, and musculoskeletal concomitants occur. The stigmata of the

*A Flemish ell measures only 27 inches, whereas an English ell equals $\mathbf{4 5}$ inches, so that the length intended by the author would have been about 13 to 14 inches. 


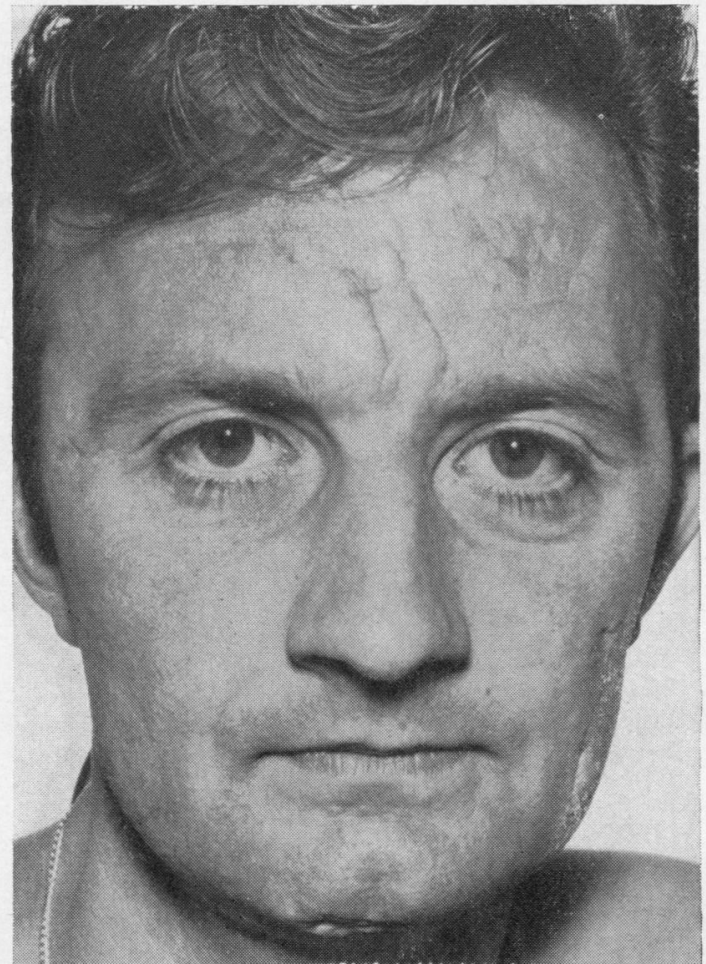

Fig. 3.-Facial scarring.

EDS have been comprehensively reviewed by McKusick (1966).

The EDS is a familial condition, which is usually inherited as an autosomal dominant trait, although an $X$-linked form of the condition has recently been described (Beighton, 1968). At the present time

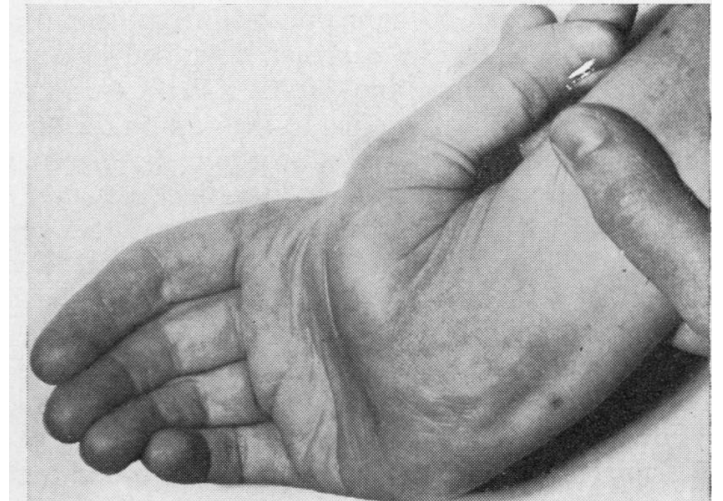

Fig. 4.-Joint hypermobility.

over 400 cases have been reported in the world literature.

\section{Patients}

\section{Present Investigation}

Fourteen patients suffering from EDS were included in the study. Details of their clinical stigmata are given in the Table. Each of the four cardinal features of the disease, namely joint hypermobility, skin hyperextensibility, scarring, and the bruising tendency, was assessed clinically and scored from 0 to 5 according to the degree of severity.

Skin thickness estimations and skin elasticity measurements were performed on all the patients and on fourteen healthy control subjects matched for age and sex.

\section{Method}

The in vivo elasticity of the skin of patients and controls was measured by a new method which

TABLE

CLINICAL DETAILS, SKIN THICKNESS MEASUREMENTS, AND SKIN ELASTICITY IN EHLERS-DANLOS PATIENTS AND CONTROL SUBJECTS

\begin{tabular}{|c|c|c|c|c|c|c|c|c|c|c|c|c|}
\hline \multirow[b]{2}{*}{$\begin{array}{l}\text { Case } \\
\text { No. }\end{array}$} & \multicolumn{8}{|c|}{14 Ehlers-Danlos Patients } & \multicolumn{4}{|c|}{14 Control Subjects } \\
\hline & Sex & $\begin{array}{l}\text { Age } \\
\text { (yrs) }\end{array}$ & $\stackrel{\text { Joint }}{\text { Hypermobility }}$ & $\begin{array}{c}\text { Skin } \\
\text { Hyper- } \\
\text { extensibility }\end{array}$ & Scarring & Bruising & $\begin{array}{c}\text { Skin } \\
\text { Thickness } \\
\text { (cm.) }\end{array}$ & $\begin{array}{c}\text { Elastic } \\
\text { Modulus } \\
\text { (dynes/ } \\
\mathrm{cm}^{2} \times \mathbf{1 0}^{8} \text { ) }\end{array}$ & Sex & $\begin{array}{c}\text { Age } \\
\text { (yrs) }\end{array}$ & $\begin{array}{c}\text { Skin } \\
\text { Thickness } \\
\text { (cm.) }\end{array}$ & $\begin{array}{c}\text { Elastic } \\
\text { Modulus } \\
\text { (dynes/ } \\
\mathrm{cm}^{2} \times 10^{2} \text { ) }\end{array}$ \\
\hline $\begin{array}{r}1 \\
2 \\
3 \\
4 \\
5 \\
5 \\
7 \\
8 \\
9 \\
10 \\
11 \\
12 \\
13 \\
14\end{array}$ & $\begin{array}{l}\mathbf{F} \\
\mathbf{F} \\
\mathbf{F} \\
\mathbf{F} \\
\mathbf{F} \\
\mathbf{F} \\
\mathbf{F} \\
\mathbf{F} \\
\mathbf{M} \\
\mathbf{M} \\
\mathbf{M} \\
\mathbf{M} \\
\mathbf{M}\end{array}$ & $\begin{array}{r}9 \\
12 \\
30 \\
31 \\
32 \\
35 \\
49 \\
50 \\
52 \\
11 \\
16 \\
25 \\
28 \\
36\end{array}$ & $\begin{array}{l}4 \\
4 \\
5 \\
5 \\
4 \\
5 \\
5 \\
3 \\
0 \\
0 \\
5 \\
4 \\
4 \\
4\end{array}$ & $\begin{array}{l}3 \\
2 \\
3 \\
4 \\
4 \\
5 \\
3 \\
3 \\
0 \\
3 \\
4 \\
5 \\
4 \\
4\end{array}$ & $\begin{array}{l}1 \\
2 \\
3 \\
1 \\
3 \\
2 \\
3 \\
2 \\
2 \\
1 \\
4 \\
5 \\
2 \\
3\end{array}$ & $\begin{array}{l}2 \\
2 \\
3 \\
2 \\
2 \\
1 \\
3 \\
2 \\
5 \\
1 \\
2 \\
4 \\
2 \\
2\end{array}$ & $\begin{array}{l}0.095 \\
0.085 \\
0.085 \\
0.07 \\
0.09 \\
0 \cdot 1 \\
0.07 \\
0.065 \\
0.09 \\
0 \cdot 1 \\
0.07 \\
0.055 \\
0 \cdot 105 \\
0.08\end{array}$ & $\begin{array}{l}3 \cdot 9 \\
2 \cdot 0 \\
3 \cdot 3 \\
3 \cdot 4 \\
4 \cdot 4 \\
3 \cdot 1 \\
2 \cdot 2 \\
2 \cdot 8 \\
4 \cdot 5 \\
2 \cdot 1 \\
1 \cdot 7 \\
2 \cdot 2 \\
1 \cdot 4 \\
1 \cdot 7\end{array}$ & $\begin{array}{l}\mathbf{F} \\
\mathbf{F} \\
\mathbf{F} \\
\mathbf{F} \\
\mathbf{F} \\
\mathbf{F} \\
\mathbf{F} \\
\mathbf{F} \\
\mathbf{M} \\
\mathbf{M} \\
\mathbf{M} \\
\mathbf{M} \\
\mathbf{M}\end{array}$ & $\begin{array}{r}7 \\
8 \\
29 \\
27 \\
30 \\
35 \\
52 \\
54 \\
52 \\
11 \\
13 \\
25 \\
30 \\
37\end{array}$ & $\begin{array}{l}0 \cdot 12 \\
0 \cdot 115 \\
0 \cdot 1 \\
0 \cdot 115 \\
0 \cdot 09 \\
0 \cdot 09 \\
0 \cdot 13 \\
0 \cdot 09 \\
0 \cdot 1 \\
0 \cdot 115 \\
0 \cdot 135 \\
0 \cdot 11 \\
0 \cdot 11 \\
0 \cdot 12\end{array}$ & 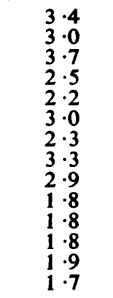 \\
\hline
\end{tabular}


enables the result to be expressed in mathematical terms. The technique has been described in detail elsewhere (Grahame and Holt, 1969). A simple suction cup device is applied to the skin on the back of the forearm and the distortion produced in response to a predetermined negative pressure is measured. A stress/strain* curve may then be constructed and the gradient of this curve, after the initial taking up of slack, represents the Elastic Modulus for intact skin.

Measurement of skin-fold thickness was also performed, using Harpenden calipers (Tanner and Whitehouse, 1955) on a fold of skin overlying the fourth right metacarpal bone. This site was chosen as it has been shown that a skin-fold in this region contains very little subcutaneous fat (McConkey, Fraser, Bligh, and Whiteley, 1963).

\section{Results}

\section{(a) Skin Elasticity}

An example of a stress/strain curve for intact skin obtained from a patient with the EDS (Patient 9) is shown in Fig. 5. A similar curve from a control subject is also shown for the purpose of comparison. It is apparent that in the affected

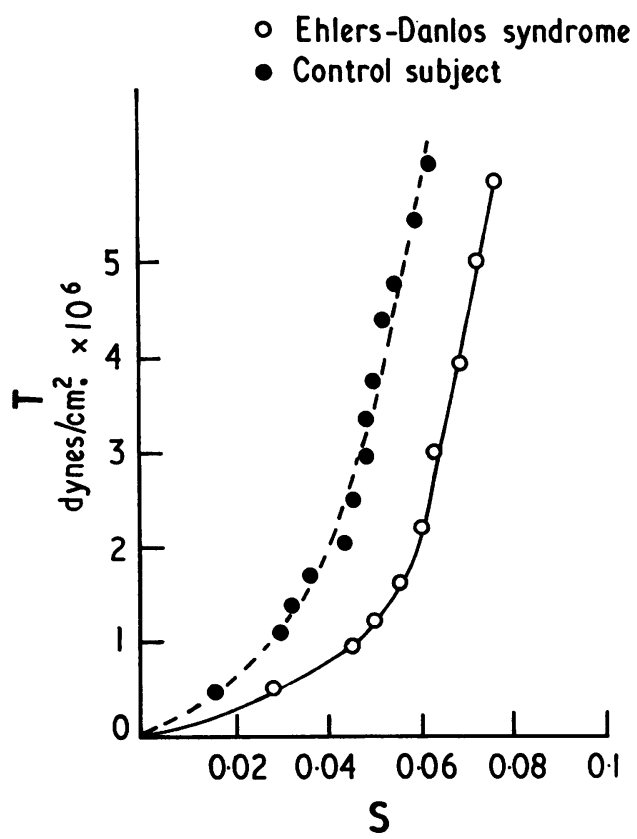

Fig. 5. - Stress/strain curve for intact skin in Ehlers-Danlos syndrome.

*Stress is defined as the force applied divided by the cross-sectional area. Strain is the distortion produced in response to stress being defined as the increase in length divided by the initial length. patient there is initially a greater degree of extensibility, but with further increases in stress, the stress/strain relationship becomes normal.

The results for the Elastic Modulus in the EDS patients and controls are shown in the Table and Fig. 6. The mean values were 3.2 (Standard Error (S.E.) \pm 0.4$)$ and 3.6 (S.E. \pm 0.3$)$ dynes $/ \mathrm{cm}^{2} \times$ $10^{8}$ respectively. The differences were not significant $(\mathrm{P}=\mathbf{0} \cdot 28)$.

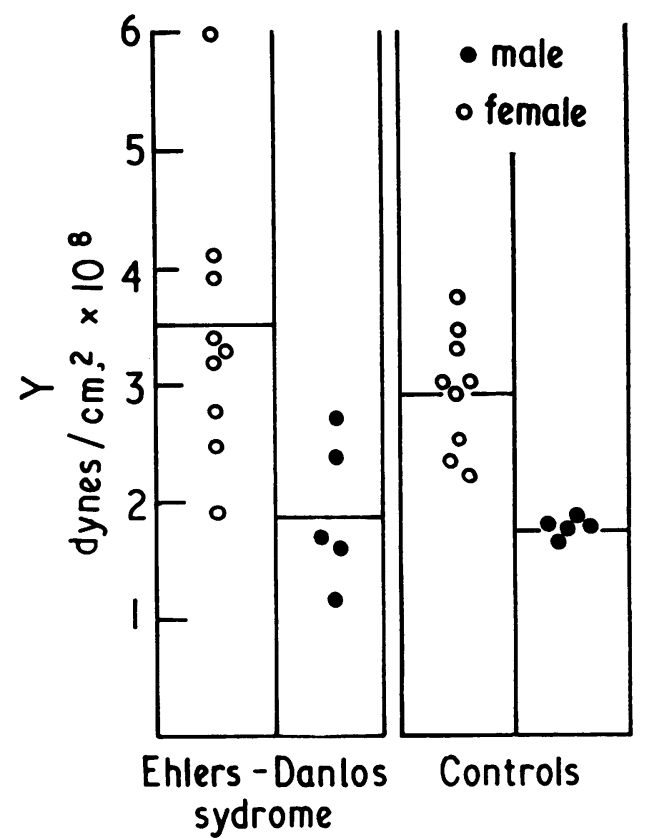

Fig. 6.-Scatter-diagram, showing Elastic Modulus for intact skin in Ehlers-Danlos patients and control subjects.

The mean value for the Elastic Modulus in the female patients was $3 \cdot 5$ (S.E. $\pm 0 \cdot 38$ ) dynes $/ \mathrm{cm} .{ }^{2} \times$ $10^{8}$ compared with 1.9 (S.E. \pm 0.03 ) dynes $/ \mathrm{cm} .{ }^{2} \times$ $10^{8}$ in the male patients. The difference is significant $(P<0.02)$. Similarly, the control group, the mean value for female subjects $(2 \cdot 9$, S.E. \pm $0 \cdot 17)$ was significantly higher than for male subjects $(1.8$, S.E. \pm 0.03$) ; P<0.001$. The finding of higher values for the elastic modulus in female skin in vivo has been a consistent observation in all previous studies using the same method, whether testing healthy subjects or patients suffering from differing pathological conditions.

In the EDS group the Elastic Modulus did not correlate with the degree of skin hyperextensibility as judged clinically, nor with any of the other scored clinical parameters, viz. joint hypermobility, scarring, or bruising. 


\section{(b) Skin Thickness}

Values for skin thickness obtained from the EDS and control subjects are shown in Fig. 7 and the Table. The mean value in the female EDS patients was $0.08 \mathrm{~cm}$. (S.E. \pm 0.004 ), compared with $0 \cdot 11 \mathrm{~cm}$. (S.E. $\pm 0 \cdot 004$ ) in the female controls. The mean value for male EDS patients was $0.08 \mathrm{~cm}$. (S.E. \pm 0.009$)$ compared with $0 \cdot 12 \mathrm{~cm}$. (S.E. \pm $0.004)$ in the male controls. In both sexes the differences were significant (females $P<0.02$; males $\mathbf{P}<0.03$ ). There was no significant difference in skin thickness between male and female patients or between male and female controls in this series.

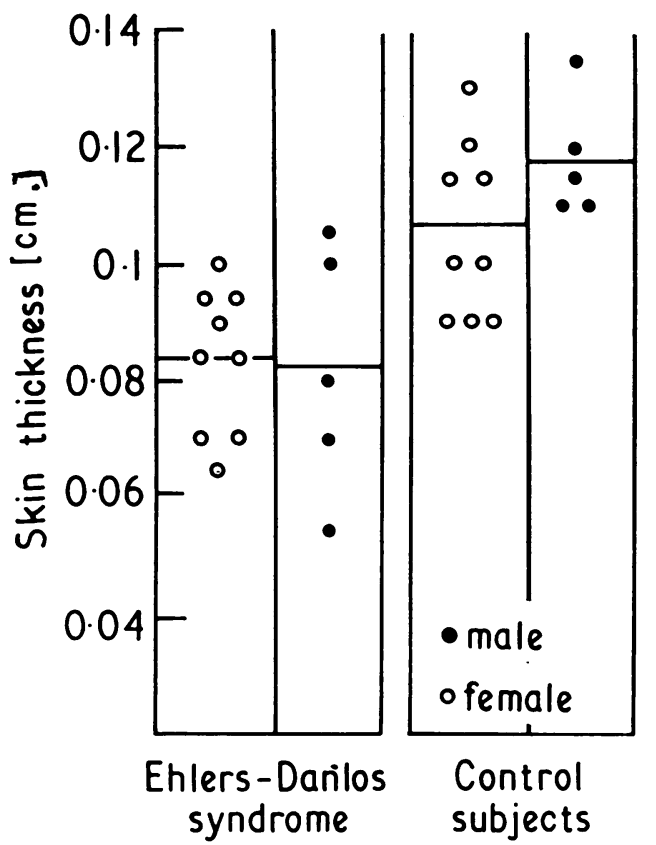

Fig. 7.-Scatter-diagram, showing skin thickness in Ehlers-Danlos patients and control subjects.

A significant inverse correlation was apparent between skin thickness and the degree of scarring in the EDS patients $(P<0.02)$, but not between skin thickness and the other scored clinical features.

\section{Discussion}

Previous studies on the tensile properties of the skin in the EDS have been limited to that of Rollhäuser (1950) who investigated ultimate tensile strength (UTS) in vitro. The patient in question was a young male aged 35 years and the result was very low in comparison with healthy males of similar age. We have been unable to find any previously reported studies of elasticity of the skin in EDS, either in vivo or in vitro.

Tregear (1966), working in vitro on pig skin, showed that the stress/strain curve for skin has two components. Initially there is considerable strain in response to relatively little stress. This phase represents the taking up of slack which occurs as the collagen fibrils become orientated in the direction of the traction applied. After about 5 per cent. strain has been achieved, the collagen fibrils themselves are subjected to the stretching force, and being relatively inextensible they yield comparatively little further strain in response to increased stress. From this point onwards, the relationship is virtually linear. Hooke's Law* may be said to apply, and the gradient may be taken to represent the Elastic Modulus for skin. The same pattern of stress/ strain relationship has been observed on testing human skin in vivo (Grahame and Holt, 1969).

In the present study the stress/strain curve for skin in EDS is found to differ from that in healthy skin (Fig. 5). This difference denotes an increased degree of extensibility which is evident only during the early phase of strain (between 2 and 5 per cent.). During this phase an identical stress results in up to twice the amount of strain in the EDS patients compared with the control subjects. As stress is further increased, this initial relative hyperextensibility on the part of EDS skin progressively diminishes until the stress/strain curves of both the EDS subjects and the controls become virtually parallel, denoting that the Elastic Modulus is almost identical in the two cases. In fact, taking the EDS patients as a whole, values for the Elastic Modulus did not differ significantly from the control group.

Since the elastic properties of skin devolve almost exclusively on the dermal collagen (Tregear, 1966), it seems likely from the above results that hyperextensibility of skin in the EDS is due to an abnormal disposition of the collagen fibrils or bundles, resulting in an abnormal mode of taking up slack, rather than to any abnormality in the elasticity of the collagen itself.

The nature of the basic defect in the EDS is still a matter for speculation. Previous studies (Tunbridge, Tattersall, Hall, Astbury, and Reed, 1952; Jansen, 1955) have shown that the ultramicroscopical appearances of collagen and elastin are normal. Jansen (1955) has also demonstrated that the quantity of both collagen and elastin in the skin in

\footnotetext{
*Hooke's Law states that stress is proportional to strain.
} 
cases of the EDS is also normal. He concluded that the abnormality in the skin was one of defective binding of the collagen fibrils which are linked together to make up the collagen bundles. It has been postulated that, because of the abnormal formation of these bundles, the fibrils are able to slide over each other more easily than normal (Strelling, 1960). The results of this study of the physical properties of the skin in the EDS are in keeping with Jansen's hypothesis.

Other authors have commented that the skin of affected patients seems to be unduly thin (Johnson and Falls, 1949). The results of the measurement of skin thickness in the present study indicate that the skin of the affected patients investigated is significantly thinner than that of the control subjects. This feature probably plays a part in the tendency of the skin to split on minor trauma, as there is a statistically significant inverse correlation between skin thickness and the degree of scarring. Another important factor, in this respect, is the reduction in the amount of subcutaneous fat in the EDS (Wallach and Burkart, 1950). It is noteworthy that skin splitting occurs most frequently over the forehead, elbows, knees, and shins, where there is relatively little subcutaneous fat to provide a cushioning effect protecting the skin from the effects of trauma. Indeed Smith (1939) put forward the view that the skin-splitting tendency could be reduced by increasing the amount of subcutaneous fat, and he was able to improve his patients' condition by means of a generous diet. The liability to skin splitting tends to diminish in some patients as they grow older. It has been suggested by Summer (1956) that this is due to an increase in the fat depots making the hypodermis a more effective buffer against trauma. Similarly, a patient described by Ronchese (1949) developed a liability to skin splitting on the disappearance of his subcutaneous fat when he was 5 years old.

\section{Summary}

An investigation of the in vivo elasticity of the skin of fourteen patients with the Ehlers-Danlos syndrome demonstrated that skin hyperextensibility in the condition occurs during the phase of taking up slack. After this has been completed, further extension is achieved only by considerable increases in stress, and values for the Elastic Modulus for intact skin in these patients did not differ from those obtained for control subjects.

The significance of these findings in relation to current theories on the basic defect in the skin in the EDS is discussed.

Measurement of skin thickness showed that the skin of affected patients was significantly thinner than in control subjects. Furthermore, a significant inverse correlation was found between the thickness and the tendency to skin splitting, as evidenced by the degree of scarring.

This investigation was supported by grants to one of us (P.B.) from the Arthritis and Rheumatism Council and the St Thomas's Hospital Endowment Fund.

Some of this work formed part of a thesis submitted by one of us (R.G.) for the Degree of M.D. of the University of London.

\section{REFERENCES}

Beighton, P. (1968). Brit. med. J., 3, 409 (X-linked recessive inheritance in the Ehlers-Danlos syndrome).

Duperrat, B. (1965). Gaz. méd. Fr., 72, 4037 (Le syndrome d'Ehlers-Danlos).

Grahame, R., and Holt, P. J. L. (1969). Gerontologia (Basel), 15, 121 (The influence of ageing on the in vitro elasticity of human skin).

Jansen, L. H. (1955). Dermatologica (Basel), 110, 108 (The structure of the connective tissue, an explanation of the symptoms of the Ehlers-Danlos syndrome).

Johnson, S. A. M., and Falls, H. F. (1949). Arch. Derm. Syph. (Chicago), 60, 82 (Ehlers-Danlos syndrome. A clinical and genetic study).

McConkey, B., Fraser, G. M., Bligh, A. S., and Whiteley, H. (1963). Lancet, 1, 693 (Transparent skin and osteoporosis).

McKusick, V. A. (1966). "Heritable Disorders of Connective Tissue", 3rd ed., pp. 179-229. Mosby, St. Louis.

Meekeren, J. A. van (1682). "De dilatabilate extraordinaria cutis", in "Observations medicochirugicae", chap. 32. Amsterdam.

Rollhäuser, H. (1950). Gegenbaurs morphol. Jahrbuch, 90, 249 (Die Zugfestigkeit der menschlichen Haut). 
Ronchese, F. (1949). R. I. med. J., 32, 80 [Dermofragility with dermo-hyperlaxity-hyperelasticity and arthro-hyperlaxity (Ehlers-Danlos syndrome)].

Smith, C. H. (1939). J. Pediat., 14, 632 [Dermatorrhexis (Ehlers-Danlos syndrome)].

Strelling, M. K. (1960). Brit. J. Derm., 72, 164 (Ehlers-Danlos syndrome).

Summer, G. K. (1956). Amer. J. Dis. Child., 91, 419 (The Ehlers-Danlosisyndrome. A review of the literature and report of a case with a subgaleal hematoma and Bell's palsy).

Tanner, J. M., and Whitehouse, R. H. (1955). Amer. J. phys. anthropol., 13, 743 (The Harpenden skinfold caliper).

Tregear, R. T. (1966). "The Physical Functions of the Skin." Academic Press, New York.

Tunbridge, R. E., Tattersall, R. N., Hall, D. A., Astbury, W. J., and Reed, R. (1952). Clin. Sci., 11, 315 (The fibrous structure of normal and abnormal human skin).

Wallach, E. A., and Burkhart, E. F. (1950). Arch. Derm. Syph. (Chicago), 61, 750 (Ehlers-Danlos syndrome associated with the tetralogy of Fallot).

Les propriétés physiques de la peau dans le syndrome d'Ehlers-Danlos

\section{RÉSUMÉ}

Une étude de l'élasticité in vivo de la peau de quatorze malades atteints du syndrome d'Ehlers-Danlos a démontré que l'hyperextensibilité de la peau dans cette affection a lieu pendant la phase de la prise du mou. Une extension ultérieure â lieu seulement aux dépens de l'augmentation considérable du stress, et le taux du module d'élasticité de la peau intacte de ces malades ne différe pas de celui des sujets témoins.

La signification de ces observations en relation des théories courantes au sujet du défaut fondamental de la peau dans le syndrome d'Ehlers-Danlos est discutée.

La mensuration de l'épaisseur de la peau a démontré que la peau des malades affectés était bien plus mince que celle des témoins. De plus, une corrélation inverse marquée avait été observée entre l'epaisseur de la peau et sa tendance à se fendiller, comme il a été démontré par le degré de cicatrisation.

\section{Propiedades físicas de la piel en el síndrome Ehlers-Danlos}

\section{SUMmario}

Una investigación de la elasticidad in vivo de la piel de catorce pacientes con el síndrome Ehlers-Danlos reveló que la hiperextensión de la piel en la condición ocurre durante la fase de estiramiento. Una vez completada esta fase, la piel sigue estirándose solamente cuando hay un aumento considerable en esfuerzo, y los valores del módulo de elasticidad de la piel intacta de estos pacientes no diferían de aquellos obtenidos en sujetos testigo. Se discute el significado de estos descubrimientos con relación a las teorías admitidas sobre el defecto básico de la piel en el síndrome EhlersDanlos. Las medidas del grosor de la piel revelaron que la piel de los pacientes afectados era significativamente más delgada que en los sujetos testigo. Más aún, se halló una correlación inversa significativa entre el grosor y la tendencia de la piel a agrietarse, como quedó evidenciado por el grado de cicatrices. 